\title{
Faktor-faktor yang Mempengaruhi Keikutsertaan Kelompok Masyarakat dalam Kegiatan Illegal logging di Kabupaten Aceh Utara
}

\author{
Factors affecting the Public Group participation \\ in Illegal logging activities \\ in North Aceh District
}

\author{
M. Rafli \\ Program Studi Agroekoteknologi, Fakultas Pertanian, Universitas Malikussaleh \\ Kampus Cot Teungku Nie, Reuleut, Muara Batu, Aceh Utara 24355, Indonesia \\ Email: m.rafli@ymail.com
}

Diterima 12 Juli 2014; Dipublikasi 1 September 2014

\begin{abstract}
Abstrak
Penelitian ini dilakukan dengan tujuan untuk mengetahui sejauh mana pengaruh faktor sosial ekonomi terhadap keikutsertaannya pada kegiatan illegal logging di Kabupaten Aceh Utara. Penelitian ini dilakukan dengan menggunakan metode survai (survey methods). Populasi yang diteliti adalah seluruh responden yang sesuai kriteria yang telah ditetapkan dan berdomisili di lokasi penelitian. Teknik sampling yang digunakan adalah stratified random sampling dua tahap (two stage stratified random sampling).Tahap pertama penetapan kecamatan dan tahap kedua adalah penetapan responden. Penelitian berlangsung di kecamatan Sawang, Nisam Antara, Simpang Keuramat, Paya Bakong, Cot Girek dan Langkahan. Selanjutnya data dianalisis dengan pengujian hipotesis dilakukan secara parsial dan serempak dengan menggunakan uji t dan uji F. Selanjutnya pengujian hipotesis dengan uji beda rata-rata (student t). Untuk menguji pengaruh variable bebas secara serempak/simultan terhadap variabel terikat (Y) digunakan uji F. Untuk menguji pengaruh variable bebas secara individu parsial digunakan uji t. Ternyata secara keseluruhan terdapat perubahan yang sangat nyata pendapatan kelompok responden pengambil manfaat dari hasil hutan sebelum dan setelah diberlakukannya moratorium logging.
\end{abstract}

Kata kunci: Moratorium Logging, pendapatan masyarakat

\begin{abstract}
This study was conducted to determine the extent of the influence of socio-economic factors of participation in illegal logging activities in the North Aceh Regency. This research was conducted using survey methods (surveying methods). The population studied were all respondents who fit the criteria established and domiciled in the study area. The sampling technique used is a two-stage stratified random sampling (two stage stratified random sampling). The first stage of the determination of the sub-district and the second stage is the determination of the respondent. The study took place in the district Sawang, Nisam Antara, Simpang Keuramat, Paya Bakong, Cot Girek and Langkahan. Furthermore, the data were analyzed with hypothesis testing done partially and simultaneously by using the test and F test Further testing the hypothesis with an average difference test (Student's $t$ ). To test the effect of independent variables simultaneously/simultaneously on the dependent variable (Y) F test was used to test the influence of independent variables used individually partial t test. It turns out that overall there is a very real change in the income group of respondents making the benefits of forest products before and after the enactment of a moratorium on logging.
\end{abstract}

Keywords: Logging Moratorium and incomes. 


\section{Pendahuluan}

Saat ini Indonesia sedang meng-hadapi berbagai masalah, antara lain peningkatan pencemaran udara, penurunan produksi oksigen, kecukupan pangan bagi 237 juta lebih penduduk Indonesia, keter-sediaan air bagi rumah tangga dan industri, peningkatan produk gas rumah kaca, dan lain sebagainya. Jika dikelola dengan baik berdasarkan azas berkesinambungan maka hutan tropis dapat diandalkan untuk meng-atasi berbagai masalah tersebut (Suhardi et al, 2002).

Hutan tropis terbesar di dunia terdapat di Indonesia. Berdasarkan luasannya hutan tropis Indonesia menempati urutan ketiga setelah Brazil dan Republik Demokrasi Kongo. Hutan-hutan Indonesia memiliki kekayaan hayati yang unik. Tipe-tipe hutan utama di Indonesia berkisar dari hutan-hutan Dipterocarpaceae dataran rendah. Indonesia juga memiliki hutan mangrove terluas di dunia. Pada awal tahun 1990-an luasnya diperkirakan 4,2 juta hektar (Foret Watch Indonesia dan Global Forest Watch, 2001)

Hutan sebagai bagian dari sumber daya alam nasional memiliki arti dan peranan penting dalam berbagai aspek kehidupan sosial, pembangunan dan lingkungan hidup. Telah diterima sebagai kesepakatan Internasional, bahwa hutan yang berfungsi memberikan manfaat penting bagi kehidupan dunia, harus dibina dan dilindungi dari berbagai tindakan yang berakibat rusaknya ekosistem dunia (Zain, 1997)

Illegal logging adalah kejahatan utama pengrusakan hutan yang saat ini menjadi masalah di Negara-negara dunia ketiga yang memiliki areal hutan yang luas. Di Indonesia kegiatan Illegal logging ini terjadi hampir di setiap wilayah untuk memenuhi kebutuhan ekonomi mereka sebagai dampak kemiskinan dan keterpurukan ekonomi yang mendera masyarakat kecil negeri ini.

Tingkat deforestasi dan degradasi hutan Aceh telah mencapai titik yang sangat memprihatinkan. Secara total, deforestasi hutan Aceh mencapai angka lebih dari 350.000 hektar selama tahun 2002-2004.
Deforestasi tersebut menyebabkan degradasi hutan Aceh semakin parah, mencapai angka 1,87 juta hektar, yang di antaranya tersebar pada $75 \%$ kawasan konservasi dan hutan lindung, termasuk di Taman Nasional Gunung Leuser (Effendi, 2006).

Tekad pemerintah Aceh untuk perang melawan praktek illegal logging tampaknya sudah tidak bisa ditawar-tawar lagi. Hal ini diwujudkan dengan pendeklarasian gerakan moratorium logging atau penghentian sementara penebangan hutan di Provinsi Nanggroe Aceh Darussalam sejak tanggal 6 Juni 2007 lalu.

Hasil wawancara penulis dengan beberapa pelaku pembalak hutan di beberapa kecamatan wilayah penyangga hutan di Kabupaten Aceh Utara antara lain Kecamatan Simpang Keuramat, Matang Kuli dan Langkahan menujukkan di wilayah ini diakui bahwa ada larangan untuk menebang kayu (moratorium logging), akan tetapi mereka tetap melakukannya. Hal ini disebabkan pekerjaan tersebut yang sudah lama mereka tekuni sebagai mata pencaharian dan sulit untuk menghentikannya karena belum ada pekerjaan pengganti.

Tradisi pengelolaan hutan yang arif bijaksana telah dipraktekkan secara turun temurun dalam masyarakat Aceh. Hal ini diselenggarakan melalui lembaga adat uteun yang dipimpin oleh Panglima Uteun. Panglima Uteun merupakan unsur pemerintahan mukim yang bertanggungjawab kepada Imum Mukim, yang tugas utamanya adalah menjaga dan mempertahankan kelestarian hutan beserta segenap isinya. Khazanah adat budaya ini masih melekat dalam kehidupan sebagian masyarakat Aceh sebagai sebuah kearifan lokal yang masih ada dan harus dipertahankan, terutama pada kemukiman yang wilayahnya berdekatan dengan kawasan hutan (Taqwaddin, 2008). Selama ini bagi masyarakat sekitar hutan, mereka berhak memanfaatkan hasil-hasil hutan yang dikaruniakan Allah kepada mereka. Kayu adalah salah satu produk hutan yang bernilai tinggi yang banyak dijadikan komoditas komersil sebagai matapencaharian masyarakat ini. Permasa- 
lahannya adalah apakah dengan diberlakukan moratorium logging ini akan merugikan masyarakat sekitar hutan, karena pendapatannya akan menurun drastis. Lebih jauh perlu dianalisis faktor sosial ekonomi yang berperan dalam menentukan keikutsertaan masyarakat dalam kegiatan illegal logging. Penelusuran dampak ini akan berkaitan dengan ketergantungan masyarakat pada hasil-hasil hutan baik kayu maupun non kayu. Jadi bila masyarakat menggantungkan mata pencaharian pada hasil kayu, apakah pendapatannya akan berkurang dan apa saja factor yang menentukan kegiatan illegal logging ini.

\section{Metode Penelitian}

\section{Lokasi dan Waktu}

Lokasi penelitian di Kabupaten Aceh Utara, dengan spesifikasi wilayah dominan wilayah hutan. Wilayah dominan hutan di Kabupaten Aceh Utara adalah Kecamatan Sawang, Nisam, Simpang Keuramat, Paya Bakong, Cot Girek dan Langkahan. Keenam kecamatan tersebut merupakan penyangga hutan yang terletak di Kabupaten Aceh Utara. Kabupaten Aceh Utara merupakan salah satu kabupaten yang relatif banyak terjadi kasus illegal logging. Oleh karena itu keenam kecamatan tersebut dianggap representatif ditetapkan sebagai lokasi penelitian untuk menelaah aspek-aspek illegal logging. Penelitian ini telah dilaksanakan sejak Februari tahun 2010.

\section{Objek dan Ruang Lingkup}

Objek penelitian ini adalah warga masyarakat yang selama ini terlibat langsung ataupun berkaitan erat dengan kegiatan logging (sebelum atau setelah pemberlakuan moratorium logging). Selain itu objek penelitian adalah bidang usaha masyarakat yang memiliki dampak dari pemberlakuan moratorium logging, baik secara teknis maupun ekonomis. Untuk itu responden ini dikelompokkan menjadi empat kategori/ profesi berdasarkan profesi/pekerjaan, yaitu : (1) pemilik modal, (2) buruh loging, (3) pedagang kayu, dan (4) pengusaha perabot. Sedangkan ruang lingkup penelitian ini terbatas pada faktor-faktor ekonomi dan sosial yang dipengaruhi akibat pemberlakuan moratorium logging di Propinsi Aceh pada tanggal 6 Juni 2007.

\section{Karaktersistik Responden}

Kerakteristik responden yang dianalisis sesuai dengan variable dan konsep yang telah diutarakan pada metode penelitian adalah umur, pendidikan dan pengalaman pada pekerjaan pokoknya. Tiga variabel yang terdiri dari umur $\left(\mathrm{X}_{1}\right)$, pendidikan $\left(\mathrm{X}_{2}\right)$, dan pengalaman pada pekerjaan utamanya $\left(\mathrm{X}_{3}\right)$; dianggap menentukan pemahamannya terhadap kegiatan illegal logging dan moratorium logging. Umur responden mencirikan karakteristik pemikiran dan pemahaman terhadap kegiatan illegal logging.

Tabel 1. Rata-rata Umur, Pendidikan dan Pengalaman Responden pada masing-masing kelompok Responden di Daerah Penelitian.

\begin{tabular}{llcccc}
\hline No & Kelompok Responden & $\begin{array}{c}\text { Jumlah } \\
\text { Sampel }\end{array}$ & $\begin{array}{c}\text { Umur } \\
\text { (tahun) }\end{array}$ & $\begin{array}{c}\text { Pendidikan } \\
\text { (tahun) }\end{array}$ & $\begin{array}{c}\text { Pengalaman } \\
\text { (tahun) }\end{array}$ \\
\hline 1. & Pemilik Modal & 18 & 50 & 9 & 9 \\
2. & Buruh Logging & 18 & 45 & 8 & 8 \\
3. & Pedagang Kayu & 12 & 51 & 11 & 9 \\
4. & Pengusaha Perabot & 12 & 46 & 11 & 12 \\
\hline & Rerata & & 48 & 10 & 9,4 \\
\hline
\end{tabular}

Sumber : Data diolah (2010) 
Demikian juga dengan pendidikan responden secara umum menentukan kadar pemahaman terhadap konsep-konsep illegal logging dan moratorium. Hasil penelitian tidak terdapat

Tabel 1 menunjukkan bahwa bahwa rata-rata umur dan pendidikan masingmasing kelompok relatif agak sama. Pada umumnya masyarakat muda dan kurang berpendidikan cenderung tidak mamahami tujuan moratorium logging ini, apalagi bersinggungan langsung dengan pekerjaan pokoknya. Pekerjaan pokok sebagai matapencaharian utama menentukan pendapatan dan ketergantungan konsumsinya. Oleh karena itu responden cenederung menolak pemahaman moratorium logging ini.

Ini artinya bahwa semua kelompok responden yang terrekam pada penelitian ini sebagian besar adalah pemain baru. Variasi pengalaman ikut serta pada kegiatan logging antara 8 sampai dengan 12 tahun, dengan rata-rata 9 tahun. Sebagian besar responden yang memodali kegiatan illegal loging ini masih kurang dari 12 tahun sejak tahun 1995 sampai tahun 2007. Pemilik modal ini sebagian kecil (4 dari 18 orang) masih melakukan kegiatan logging walaupun telah dilakukan razia besar-besaran di seluruh wilayah Provinsi Aceh. Sebagian besar (14 dari 18 orang) mengalihkan usahanya ke bidang lain, dengan struktur produksi yang jauh berbeda. Dari sisi pengalaman pemilik modal yang mengalihkan usahanya ini jauh lebih tinggi dibandingkan dengan pemodal yang masih bertahan dengan cara beroperasi disela-sela kelengahan petugas.

\section{Metoda Analisis dan Pengujian Hipotesis}

Data yang telah dikumpulkan kemudian ditabulasi dan dibuat dalam bentuk tabelaris yang sesuai dengan kebutuhan analisis. Pengujian hipotesis dilakukan secara parsial dan serempak dengan menggunakan uji $t$ dan uji $F$. Selanjutnya digunakan Model Analisis Regresi Linier Berganda dimana terdapat sejumlah variable bebas yang dihubungkan dengan satu variable terikat (tidak bebas). Jika variable bebas dalam penelitian ini adalah $\mathrm{X}_{1}, \quad \mathrm{X}_{2}, \ldots \ldots, \mathrm{X}_{9}$ dan variable variasi karakteristik responden yang nyata pada masing-masing kelompok responden, seperti yang ditunjukkan pada Tabel 1 .

terikatnya adalah Y, maka bentuk rumus dari Regresi Linier Berganda adalah sebagai berikut (Sujana, 1992) :

$Y=a_{0}+a_{1} X_{1}+a_{2} X_{2}+a_{3} X_{3} \ldots . .,+a_{9} X_{9}+e$

Dimana :

$\mathrm{Y}=$ Kadar keikutsertaan pada kegiatan ilegal logging $(\%)$

$\mathrm{X}_{1}=$ Umur responden (tahun)

$\mathrm{X}_{2}=$ Lamanya pendidikan (tahun)

$\mathrm{X}_{3}=$ Pengalaman bekerja di sektor logging (tahun)

$\mathrm{X}_{4}=$ Pendapatan sebelum moratorium logging (Rp/tahun)

$\mathrm{X}_{5}=$ Pendapatan setelah Moratorium Logging (Rp/tahun).

$\mathrm{X}_{6}=$ Tenaga kerja yang dipekerjakan pada pekerjaan utama (H OK)

$\mathrm{X}_{7}=$ Besarnya biaya untuk konsumsi keluarga (Rp/thn)

$\mathrm{X}_{8}=$ Kadar pemahaman terhadap moratorium logging $(\%)$

$\mathrm{X}_{9}=$ Intensitas penyuluh (frekwensi/ tahun)

$\mathrm{a}_{0}=$ Konstanta

$\mathrm{a}_{1}, \mathrm{a}_{2}, \mathrm{a}_{3}, \ldots . . \mathrm{a}_{9}=$ Parameter yang Dicari

$\mathrm{e}=$ Error

Untuk menguji pengaruh variable bebas $\left(\mathrm{X}_{1}, \mathrm{X}_{2}, \mathrm{X}_{3}, \ldots, \mathrm{X}_{9}\right)$ secara serempak/ simultan terhadap variabel terikat (Y) digunakan uji $\mathrm{F}$ dengan rumus sebagai berikut (Sujana, 1992),

$$
\mathrm{F}=\frac{\mathrm{R}^{2} / k}{\left(1-\mathrm{R}^{2}\right)(\mathrm{n}-\mathrm{k}-}
$$

Dimana :

$$
\begin{aligned}
& \mathrm{R}^{2}=\text { Koefisien Determinasi } \\
& \mathrm{k}=\text { Jumlah Variabel Bebas } \\
& \mathrm{n}=\text { Jumlah Sampel }
\end{aligned}
$$

Dengan kaedah keputusan :

Bila $\mathrm{F}$ cari $<$ F table $(\mathrm{a}=0,05)$, maka terima Ho dan tolak Ha

Bila $\mathrm{F}$ cari $>\mathrm{F}$ table $(\mathrm{a}=0,05)$, maka terima $\mathrm{Ha}$ dan tolak Ho 
Dimana hipotesis :

Ho : $\mathrm{a}_{\mathrm{i}}=\mathrm{o}$; Variabel bebas $\left(\mathrm{X}_{1}, \mathrm{X}_{2}, \mathrm{X}_{3}\right.$, ., $\mathrm{X}_{9}$ ) berpengaruh tidak nyata terhadap variabel terikat $\mathrm{Y}$

$\mathrm{H} 1: \mathrm{a}_{\mathrm{i}} \neq \mathrm{o}$; Variabel bebas $\left(\mathrm{X}_{1}, \mathrm{X}_{2}, \mathrm{X}_{3}, \ldots\right.$, $\left.X_{9}\right)$ berpengaruh nyata terhadap variable terikat Y.

Selanjutnya untuk menguji keeratan hubungan antara variabel bebas $\left(\mathrm{X}_{1}, \mathrm{X}_{2}, \mathrm{X}_{3}\right.$, ..., $\mathrm{X}_{9}$ ) dengan variabel terikat (Y) digunakan Koefisien Variabel (r), dengan rumus sebagai berikut (Sujana, 1992 ):

Dimana :

$$
\mathrm{R}^{2}=\frac{\mathrm{JK}(\mathrm{reg})}{\sum \mathrm{Yi}^{2}}
$$

$\mathrm{R}^{\mathbf{2}}=$ Koefisien Determinasi

$\mathrm{JK}($ reg) $=$ Jumlah Kuadrat untuk Regresi

$\mathrm{Yi}=$ Jumlah kuadrat total

Untuk menguji pengaruh variable bebas (X1, X2, X3, ...., X9), secara individu/parsial digunakan uji $\mathbf{t}$ dengan rumus sebagai berikut (Sujana. 1992) :

$$
{ }_{\text {cari }}^{\mathrm{T}}=\frac{\mathrm{a}_{\mathrm{i}}}{\mathrm{Sa}_{\mathrm{i}}}
$$

Dimana : $a_{i}=$ Koefisien Regresi Variabel Xi $\quad(i=1,2,3, \ldots . ., 9)$

$\mathrm{Sa}_{\mathrm{i}}=$ Standar Error Variabel $\mathrm{Xi} \quad(\mathrm{i}=$ $1,2,3, \ldots . ., 9)$

Dengan kaedah keputusan sebagai berikut :
Bila t cari $<\mathrm{t}$ tabel $(\mathrm{a}=0,05)$, maka terima Ho tolak Ha

Bila t cari $>\mathrm{t}$ table $(\mathrm{a}=0,05)$, maka terima Ha tolak Ho

\section{Hasil dan Pembahasan}

Keikutsertaan dalam Kegiatan Illegal Logging

Keikutsertaan dalam illegal logging diukur dengan penyertaan modal dan kontribusi penghasilan masyarakat pada kegiatan tersebut. Semakin besar modal yang disertakan dalam kegiatan illegal logging, maka semakin besar pula perannya dalam kegiatan tersebut. Demikian sebaliknya semakin kecil penyertaan modalnya maka semakin kecil perannya dalam kegiatan illegal logging. Penyertaan modal dalam kegiatan illegal loging dapat diukur dari besarnya modal yang ditanggung oleh pemilik modal dan pelaku kegiatan yang diukur dengan persentase. Demikian juga dengan kontribusi penghasilan dari kegiatan illegal loging tersebut mulai dari kegiatan penebangan kayu di hutan, pengangkutan, perdagangan, pengolahan kayu dan pemanfaatannya.

Hasil penelitian menunjukkan terdapat peran yang berbeda masing-masing kelompok masyarakat dan kontribusi modal serta penghasilan untuk dan dari kegitan illegal logging tersebut, seperti yang ditunjukkan pada Tabel 2.

Tabel 2. Keikutsertaan Responden Dalam Kegiatan Illegal Logging, Permodalan dan Penghasilan dari Kegiatan Illegal Logging.

\begin{tabular}{llccc}
\hline \multirow{2}{*}{ No. } & \multirow{2}{*}{ Peran } & \multicolumn{3}{c}{ Penyertaan Modal dan Kontribusi Penghasilan (\%) } \\
\cline { 3 - 5 } & & Modal & Penghasilan & Total \\
\hline 1. & Pemilik Modal & 89.6 & 91.2 & 90.4 \\
2. & Buruh Logging & 91.1 & 83.3 & 87.2 \\
3. & Pedagang Kayu & 62.5 & 70.9 & 67.9 \\
4. & Pengusaha Perabot & 65.6 & 70.9 & 68.3 \\
\hline \multicolumn{2}{l}{ Rerata } & 79.8 & 80.7 & 80.5 \\
\hline
\end{tabular}

Sumber: Data Diolah (2010)

Pada tabel 2 ditunjukkan peran serta dalam bentuk penyertaan modal dan sebagai sumber penghasilan utama kelompok responden. Bagi pemilik modal, peran serta sebagai penyandang dana kegiatan illegal loging bervariasi antara 70 sampai dengan 
98 persen. Perbedaan peran serta modal ini ditentukan oleh faktor kepercayaan dan rencana pembagian hasil. Semakin dipercaya pelaku illegal loging, semakin berani penyandang dana ini memberikan modal kepada pelakunya, sebaliknya untuk tim yang baru biasanya pemodal sedikit lebih berhati-hati. Disamping itu dalam penyertaan modal ini juga diatur rencana pembagian penghasilan dari kegiatan ini. Semakin besar modal yang disertakan semakin besar pula penghasilan yang diterimanya.

Pada tabel di atas ditunjukkan komponen yang paling besar peranannya pada kegiatan illegal logging adalah pemilik modal dan buruh logging. Kedua komponen tersebut ada kalanya bekerjasama dengan sangat erat. Akan tetapi terdapat 14 responden buruh kayu yang tidak menerima bantuan modal pada saat melakukan kegiatannya. Buruh logging ini menggunakan peralatan sendiri, dan dibantu oleh anggota keluarganya melakukan kegiatan penebangan kayu, pengangkutan kayu dan menjualnya sendiri ke pedagang kayu log. Terdapat empat orang buruh kayu ini yang sepenuhnya dibiayai oleh pemodal. Oknum ini menyerahkan peralatan penebangan kayu dan alat transportasi kayu kepada buruhnya, kemudian hasil kayu jarahan ditampung untuk kemudian dijual kepada Pedagang Kayu atau perabot. Bentuk kayu gelon- dongan dijual ke Pedagang Kayu untuk kemudian diolah menjadi broti atau papan. Sedangkan bentuk olahan kasar broti dan papan yang dikerjakan di hutan dijual kepada pengusaha perabot.

Pengusaha panglong sering pula terlibat sebagai pemodal, sehingga komponen pembiayan dalam kegiatan illegal logging ini bertambah. Pedagang Kayu memberikan alat pemotong kayu dan alat transportasi kayu kepada buruh kayu untuk kemudian hasil kayu jarahan ditampung oleh Pedagang Kayu tersebut.

\section{Faktor-faktor Yang Berpengaruh Terhadap Keikutsertaan Masyarakat Pada Kegiatan Illegal Logging}

Moratorium logging telah diberlakukan dua tahun yang lalu, akan tetapi kegiatan penebangan kayu, pengolahan kayu, pemanfataan hasil kayu dan perdagangan kayu di Kabupaten Aceh Utara masih terus berlangsung. Oleh karena itu dalam formulasi masalah penelitian ini menetapkan sepuluh variabel yang menentukan keikutsertaan masyarakat dalam kegiatan illegal logging. Hasil penelitian menunjukkan bahwa terdapat koefisien faktor yang menentukan keikutsertaan masyarakat dalam kegiatan illegal loging yang signifikan seperti yang disajikan pada Tabel 3.

Tabel 3. Koefisien Faktor Penentu Keikutsertaan Dalam Kegiatan Illegal Logging

\begin{tabular}{lcccc}
\hline \multirow{2}{*}{ Variabel } & \multicolumn{2}{c}{ Koefisien } & \multirow{2}{*}{$\mathrm{t}$} & \multirow{2}{*}{ Sig. } \\
\cline { 2 - 3 } & $\mathrm{B}$ & \multicolumn{1}{c}{ Std. Error } & & \\
\hline Constant $)$ & 96.293 & 15.068 & 6.39 & 0 \\
Umur $\left(\mathrm{X}_{1}\right)$ & -0.133 & 0.305 & -0.435 & 0.665 \\
Pendidikan $\left(\mathrm{X}_{2}\right)$ & 2.625 & 0.856 & -3.066 & 0.003 \\
Lama Pekerjaan $\left(\mathrm{X}_{3}\right)$ & -0.354 & 0.239 & -1.482 & 0.145 \\
Pendapatan sebelum $\left(\mathrm{X}_{4}\right)$ & 0.509 & 0.083 & 6.103 & 0.000 \\
Pendapatan setelah $\left(\mathrm{X}_{5}\right)$ & -0.153 & 0.037 & -4.135 & 0.000 \\
Tenaga Kerja $\left(\mathrm{X}_{6}\right)$ & 0.065 & 2.071 & 0.032 & 0.975 \\
Konsumsi $\left(\mathrm{X}_{7}\right)$ & -0.05 & 0.173 & -0.287 & 0.775 \\
Kadar Pemahaman $\left(\mathrm{X}_{8}\right)$ & 0.328 & 0.154 & 2.13 & 0.004 \\
Intensitas Penyuluhan $\left(\mathrm{X}_{9}\right)$ & -0.057 & 0.762 & -0.075 & 0.941 \\
\hline
\end{tabular}

Sumber: Data diolah $(2010$ 
Dalam bentuk persamaan regresi faktor penentu keikutsertaan dalam kegiatan illegal logging dapat dituliskan sebagai berikut:

$$
\begin{aligned}
Y= & 96,293-0,133 X_{1}+2,625 X_{2}-0,354 \\
& X_{3}+0,509 X_{4}-0,153 X_{5}+0,065 \\
& X_{6}-0,05 X_{7}+0,328 X_{8}-0,057 X_{9} \\
& +\varepsilon
\end{aligned}
$$

dengan $\mathrm{R}^{2}=0,639$, artinya 63,9 persen variasi yang terdapat pada keikutsertaan masyarakat dalam kegiatan illegal logging ditentukan oleh sepuluh faktor di atas. Sedangkan 36,1 persen lain yang ditentukan oleh faktor lain di luar model. Dengan demikian masih banyak faktor lain yang seharusnya dianalisis untuk mengkaji faktor penentu illegal logging ini. Koefisien korelasi $\mathrm{R}=0,799$, artinya hubungan antara sepuluh variable bebas di atas dengan kegiatan illegal logging adalah sebesar 79,9 persen. Ini sangat nyata korelasi di antara variable bebas dan variable terikat. Uji serempak menunjukkan bahwa persamaan di atas sangat berarti seperti yang ditunjukkan pada Tabel 23 berikut ini.

Tabel 23. Analisis Varian dan Keberartian Regresi (ANOVAb)

\begin{tabular}{llccccc}
\hline Model & & Sum of Squares & df & Mean Square & F & Sig. \\
\hline 1 & Regression & 8941.205 & 9 & 993.467 & 9.820 & $.000^{\mathrm{a}}$ \\
& Residual & 5058.435 & 50 & 101.169 & & \\
& Total & 13999.640 & 59 & & & \\
\hline
\end{tabular}

a = Predictors: (Constant), Intensitas Penyuluhan, Tenaga Kerja, Pendidikan, Lama Pekerjaan, Konsumsi, Umur, Kadar Pemahaman, Pendapatan Sebelum, Pendapatan Setelah Moratorium Logging; $b=$ Dependent Variable: Keikutsertaan Illegal loging

Secara parsial terlihat bahwa hanya empat dari sepuluh faktor yang secara nyata terhadap keikutsertaan responden pada kegiatan illegal logging ini. Faktor yang signifikan andalah: pendidikan, pendapatan sebelum moratorium logging dan pendapatan setelah moratorium logging, serta kadar pemahaman mereka terhadap kebijakan ini. Pendidikan sangat penting untuk menangkap pesan-pesan dalam kebijakan moratorium logging. Semakin tinggi pendidikan semakin sadar mereka terhadap moratorium logging tersebut, sehingga keikutsertaan mereka dalam kegiatan illegal loging semakin kecil. Sebaliknya sebagian besar responden yang memiliki pendidikan rendah semakin kecil kesadarannya terhadap kebijakan moratorium logging. Oleh karena itu semakin rendah pendidikannya semakin besar keikutsertaannya dalam kegiatan illegal logging.

Pendapatan sebelum moratorium logging $\left(\mathrm{X}_{4}\right)$ berpengaruh signifikan terhadap keikutsertaan responden pada kegiatan illegal logging. Semakin besar pendapatan mereka sebelumnya semakin besar pula keikutsertaannya dalam kegiatan penebangan, pengolahan, pemanfaatan dan perdagangan kayu dan hasil ikutannya. Sebaliknya bila sebelumnya pendapatannya juga kecil maka semakin kecil pula keikut sertaannya pada kegiatan ini. Volume kegiatan penyandang modal, buruh logging, pedagang kayu dan pengusaha perabot erat kaitannya dengan perambahan hutan dan penebangan kayu secara illegal. Apalagi setelah diberlakukannya moratorium logging, ini artinya bahwa tidak dibenarkan penebangan kayu sementara kebijakan ini diberlakukan. Akan tetapi sampai saat setelah diberlakukan volume kegiatan penebangan kayu, pengolahan dan pemanfaatan kayu hanya sedikit berkurang. Hal ini juga terlihat dari pengaruh pendapatan responden terhadap keikutsertaan mereka dalam illegal logging.

Koefisien regresi pendapatan setelah moratorium logging adalah negative. Artinya bahwa $\mathrm{n}$ responden semakin kecil. Demikian juga keikutsertaannya pada kegiatan illegal 
logging semakin lama semakin kecil. Bila pendapatan responden semakin besar yang bersumber dari pekerjaan sampingan, maka semakin kecil keikutsertaannya pada kegiatan illegal logging. Ini artinya setelah moratorium logging, sebagian besar responden mulai beralih pekerjaan dari kegiatan penebangan kayu, pengolahan kayu, pemanfaatan hasil kayu dan perdagangannya.

Variabel kadar pemahaman responden terhadap moratorium logging $\left(\mathrm{X}_{9}\right)$ merupakan variabel keempat yang berpengaruh nyata terhadap keikutsertaannya pada kegiatan illegal logging. Semakin tinggi kadar pemahamannya, semakin keccil keikutsertaanya pada kegiatan illegal logging. Pemahaman moratorium yang dijelaskan kepada responden meliputi aspek ekologis, hukum, dan ekonomi. Melaksanakan jeda penebangan kayu untuk memberikan kesempatan kepada hutan menyediakan hasil secara berkesinambungan tanpa mengurangi manfaat ekologis, dan ekonomis. Responden yang sadar makna dan tujuan moratorium ini, secara signifikan mengurangi dan bahkan sebagian menghentikan keterlibatan pada illegal logging ini.

Disamping empat variable $\left(\mathrm{X}_{2}, \mathrm{X}_{4}\right.$, $\mathrm{X}_{5}$, dan $\mathrm{X}_{9}$ ) yang signifikan, variable lainnya juga berpengaruh tidak signifikan terhadap keikutsertaannya pada kegiatan illegal logging. Artinya secara statistik lima variabel lain tidak signifikan, akan tetapi variabel tersebut juga menentukan keikutsertaannya pada kegiatan illegal logging.

Uji Kolinieritas, yang dianalisis dari nilai Durbin Watson >1.96 menunjukkan bahwa tidak terdapat hubungan kolinier pada variabel bebas. Artinya semua variable secara mandiri menentukan keikutsertaan pada kegiatan illegal logging. Demikian juga uji Heteroskedatik yang ditunjukkan nilai VIF $<2$, menuntukkan tidak terdapat gejala heteroskedatik pada fungsi regressi yang menggambarkan faktor keikutsertaan pada kegiatan illegal logging ini.

Pembahasan tentang faktor penentu keikutsertaan pada kegiatan illegal loging berdasakan sepuluh variable di atas didasar- kan pada teori-teori yang telah dibahas pada tinjauan pustaka. Masyarakat di sekitar hutan di enam kecamatan di atas telah akrab dengan kondisi hutan dan terikat dengan mata pencaharian mereka. Oleh karena itu umur, pendidikan, lamanya menekuni pekerjaan pada kegiatan logging, pendapatan sebelum dan setelah moratorium logging, ketersediaan tenaga kerja keluarga, konsumsi keluarga, pemahaman terhadap moratorium logging dan intensitas penyuluhan yang diikuti diduga menentukan keikutsertaannya pada kegiatan illegal logging. Kegiatan illegal logging yang dikerjakan masyarakat sekitar hutan di enam kecamatan ini, menurut mereka adalah sah/legal. Hutan diciptakan untuk mendukung kehidupan mereka, dan mereka merasa berhak untuk memperoleh penghidupan dari hasil hutan tersebut. Oleh karena itu faktor di atas ada yang dominan menentukan dan ada pula yang tidak signifikan mempengaharuhi keikutsertaan mereka dalam penebangan, pengolahan, pemanfaatan hasil kayu dan perdagangannya. Selama ini kegiatan sosialisasi telah banyak dilakukan mulai dari pengadaan leaflet, brosur dan himbauan melalui media massa, sampai penyuluhan kepada masyarakat. Akan tetapi terlihat intensitas penyuluhan tidak signifikan pengaruhnya terhadap kegiatan illegal logging. Ini artinya bahwa kegiatan sosialisasi dan penyuluhan yang dilakukan belum efektif.

Untuk memastikan moratorium logging dapat berlangsung maka empat variabel penentu di atas dapat digunakan sabagai indikator kinerja. Pendidikan masyarakat tentang aspek ekologis, pemanfataan kayu yang efisien dan aspek hukum illegal logging dapat dimasukkan dalam materi pendidikan masyarakat. Upaya lain adalah menyelenggarakan pemberdayaan masyarakat untuk meningkatkan mata pencahariannya, memanfaatkan hasil hutan selain kayu. Pendapatan adalah faktor penting untuk mengendalikan prilaku menyimpang dari sudut hukum, ekonomi dan ekologis. Oleh karena itu pemerintah Kabupaten Aceh Utara harus fokus pada 
pemberdayaan ekonomi masyarakat sekitar hutan untuk mendukung kebijakan moratorium logging ini.

\section{Kesimpulan}

Faktor yang secara nyata berpengaruh terhadap keikutsertaan responden pada kegiatan illegal logging ini adalah pendidikan, pendapatan sebelum moratorium logging dan pendapatan setelah moratorium logging, serta kadar pemahaman mereka terhadap kebijakan moratorium logging.

\section{Daftar Pustaka}

Antariksa, B. 2009. Medan Bisnis Online. 01-052009. Diakses pada 9 Agustus 2009

Awang, S.A. 1999. Pengembangan Hutan Rakyat di Jawa Tengah : Harapan dan Tantangan. Jurnal Hutan Rakyat. Vol. 1 No. 1. Yogyakarta

Brown, D.W. 1999. Addicted to Rent: Coporate and Spatial Distribution of Forest Resources in Indonesia; Implications for Forest sustainability and Government Policy. Tropical Forest Management Program. Jakarta, Indonesia.

Chip Fay dan Martua Sirait. 2003. Kemana Harus Melangkah ? Masyarakat, Hutan dan Perumusan Kebijakan di Indonesia. Yayasan Obor Indonesia. Jakarta.

Contreras dan Hermosilla.1997. Country Sector Planning. Makalah disajikan pada Kongres
Kehutanan Dunia ke- II. Antalya. Turki

Departemen Kehutanan RI. 1986. Sejarah Kehutanan Indonesia (Indonesia Foresty History I). Jakarta, Indonesia : Departemen Kehutanan

Direktorat Jenderal Kehutanan. 1979. Rapat Kerja Instansi Kehutanan Se- Indonesia 1979 Buku II: Ceramah dan Pidato Pengarahan. Jakarta, Indonesia: Departemen Pertanian

Forest Watch Indonesia dan Global Forest Watch, 2001. Potret Keadaan Hutan Indonesia. FWI/GFW. Bogor.

Gumay D, 2008 Hutan Hancur, Satwa Liar Turun Gunung . 25 Aguststus 2008 Dari Webpage di http://www.wordpress.com. Di akses pada 10 September 2009

Iswanto, H. 1996. Pendekatan Partisipatif dalam Pembinaan Masyarakat Desa Hutan.Lokakarya Bina Desa Hutan, Balik Papan

Jackson, K.D. 1978. Bureaucratic policy A theoretical framework for the analysis of power and the communications in Indonesia. Dalam Political Power and Communication in Indonesia, disunting oleh K.D. Jackson dan L. Pye. Barkeley: University of California Press, 3-22

Kartawinata, 1991. Krisis Biologi. Hilangnya Keanekaragaman Biologi

Kompas online. Hutan Aceh Rusak. Sabtu, 29 Juli 2007. Dari webpage Hr. Kompas di http://www.kompas.com. Di akses pada 18 Agustus 2009. 